\title{
Guernica Remakings:
}

\section{Action, Collaboration and Thread}

\section{Nicola Ashmore}

School of Humanities

University of Brighton

Brighton, UK

n.ashmore@brighton.ac.uk

\section{Biographical statement}

Nicola Ashmore is a Senior Lecturer in History of Art and Design at the University of Brighton. 


\begin{abstract}
Reworkings of Pablo Picasso's Guernica include versions in textile that have been produced or exhibited in recent years. Amongst these is Remaking of Picasso's Guernica as a Protest Banner, an initiative in which the author herself was involved. Focusing on the ideas and concerns that underpinned the production of this banner, the author explains the significance of its deployment in public sewing events held in 2013 and 2014 Comparison is also drawn between the banner and two other reworkings of the Picasso painting in textile - a 1955 version that was included in an exhibition by Goshka Macuga called The Nature of the Beast that was held at the Whitechapel Gallery in London between 2009 and 2010, and The Keiskamma Guernica, a work made in South Africa that was completed in mid-2010.

It is suggested that these various reworkings point to the amenability of the Guernica to be adapted to convey a statement of opposition to those in power who prioritize their own agendas to the detriment of civilians. But whereas Picasso produced his work solitarily, its reworking or reinterpretation in textile has enabled it to be made by collectives and/or to serve as a forum for group activism.
\end{abstract}

Keywords: Picasso; Guernica; reproductions; Keiskamma; Khadi; Kuffiyah; protest banner; collaboration. 


\section{Introduction}

My views in this article have been formed as both an artist and an art and design historian. In 2012, I joined a collective of activists, artists and academics from Brighton, UK, who had gathered together to embark on the recreation of Pablo Picasso's Guernica (Figure 1) as a protest banner. We were galvanized into action by the rise in fascist groups across Europe, the presence of Islamophobia in the media and the increasing use of drones to attack civilian targets. This banner-making experience would in turn have an impact upon my research. In 2015, I conducted a series of research trips in which I carried out archival research and interviews with others who had been involved in collective reworkings of the Guernica. Visits to London and New York as well as Edmonton in Canada and the village of Hamburg in South Africa gave me a greater understanding of the materiality and physical context of these various reworkings of Picasso's famous painting.

Remaking of Picasso's Guernica as a Protest Banner, which is at the center of this article and forms its main case study, transforms Picasso's anti-war painting into an anti-war textile banner. While Guernica was chosen to be remade because of its iconic anti-fascist status, this strategy also involved critically revising the mode of making and expression in the banner. Picasso as the singular male artist is replaced by collective making, the distinction between art and craft is traversed, and embroidery is taken out of the private studio or domestic setting and is made in the public realm, with public participation (Ashmore and Rajguru, 2013). The banner provides an interesting case study as it follows a feminist tradition in the sense that it involved needlework, thus paying homage to creative work associated historically (at least in the West) with women, and was created by a predominantly female collective to comment on contemporary atrocities against civilian populations to prompt political engagement. 
The banner is not the first reworking of Picasso's Guernica, or the first to translate the work into textile. For example, in 1955 in France, the Cavalaire Atelier of J. De La BaumeDürrbach wove three Guernica tapestries that were sanctioned by Pablo Picasso who signed off the preparatory sketches and photographs of the finished works. ${ }^{1}$ One of these was purchased whilst still being woven by Nelson Rockefeller who titled it the Tapestry After Guernica. ${ }^{2}$ The Tapestry After Guernica was used in an exhibition by Goshka Macuga entitled The Nature of the Beast that was held between April 2009 and April 2010 at the Whitechapel Gallery in London. In this article, I examine this exhibition as an instance of socially purposeful art-making, relating it to the production of the protest banner with which I was involved. I also discuss the large-scale textile work, The Keiskamma Guernica, that was made in South Africa and exhibited for the first time in July 2010. Unlike the banner and the Rockefeller versions, which have been faithful to Picasso's imagery, the South African reworking involved finding motifs that could serve as local equivalents to Picasso's visual language.

While the Guernica (Figure 1) has been the subject of an extensive range of publications, including studies that focus on its psychoanalytic significance (Arnheim, 1964), narrative content (Russell, 1979) and religious associations (Fermandez, 1981), there has also been some academic work on parodies or reworkings of it. Gijs van Hensbergen (2004) wrote about the status Guernica has accumulated as a twentieth-century icon, and individual remakings have also received attention. The Rockefeller Tapestry After Guernica (1955) has been the subject of a journal article by K.L.H Wells (2015) as well as a catalogue accompanying an exhibition between 2014 and 2015 at the San Antonio Museum of Art titled Nelson Rockefeller's Picassos: Tapestries Commissioned for Kykuit. The Keiskamma Guernica (2010) has been explored in detail by Brenda Schmahmann in a journal article (Schmahmann 2015) and a book about the Keiskamma Art Project (Schmahmann 2016). But 
the banner has previously received less sustained attention. Megha Rajguru and I have contributed conference papers on its making (Ashmore and Rajguru 2014) and I have produced three short documentary films on it (Ashmore 2016 a) as well as making films on the The Nature of the Beast (Ashmore 2016 b) and The Keiskamma Tapestry (Ashmore 2016 c). This is, however, the first article focusing on that work and it reveals details about it not evident in other studies.

I suggest in this article that both the banner as well as The Nature of the Beast exhibition and The Keiskamma Tapestry point to the amenability of the Guernica to be adapted to convey a statement of opposition to those in power who prioritize their own agendas to the detriment of civilians. The Remaking of Picasso's Guernica as a Protest Banner makes connections between historic and current government-led aerial attacks on civilian populations through its presence at protests, including those held against the bombing of Gaza in the summer of 2014 in the United Kingdom. Macuga's The Nature of the Beast uses the Rockefeller Guernica tapestry to contest the 2003 United States-led Iraq invasion. The Keiskamma Guernica challenges the South African government's refusal to comprehensively respond to the HIV and AIDS epidemic. But whereas Picasso produced his work solitarily, its reworking or reinterpretation in textile has enabled it to be made by collectives and/or to serve as a forum for group activism.

I begin this article by briefly highlighting Picasso's intention for the Guernica to be reproduced and circulated widely. The banner is then examined; I focus on the horse that I was involved in making and how collaboration has impacted the process of creating the banner. The political meanings of the materials integrated into the banner are then discussed before attending to the banner's construction through a series of events involving public sewing. Thereafter I look at the incorporation of the Rockefeller tapestry in The Nature of the Beast as well as discussing The Keiskamma Guernica, drawing connections and comparisons 
between these initiatives and the Remaking of Picasso's Guernica as a Protest Banner.

\section{Picasso's Guernica}

As is well known, Picasso's Guernica responded to the dropping of bombs on the town of Gernika by forces working in co-operation with Francisco Franco during the Spanish Civil War. First shown at the Paris World Fair in 1937, it proceeded thereafter on a European tour. The work would remain in the United States from 1939 until 1981. Eventually returned to Spain, the painting has been in the Reina Sofia Museum in Madrid since 1992.

Picasso began his preparatory sketches for Guernica on May 1, 1937. The photographer Dora Maar documented the painting's metamorphosis at Picasso's Paris studio, visiting regularly from the May 11 until June 4, 1937 (Salanova 2017). Picasso was able to see how his very large canvas worked on a much smaller scale through the medium of photography, a process that interested him (Salanova 2017). Ultimately the image of Guernica circulated widely in hand-held form as a postcard. ${ }^{3}$

The ongoing deployment of reworked versions of Guernica as a form of political action could be understood to realize an intention of Picasso to use the painting to rally support and resistance against fascism. The price of admission to see Guernica at the Whitechapel Gallery in England in 1939 was a pair of boots in a fit state to be sent to the Spanish front to help the democratically-elected Republican government of Spain fight against the military coup led by Franco. The donated boots were in fact lined up at the base of the painting (Van Hensbergen 2004, 95). This tour was part of a larger appeal to raise awareness of the growing humanitarian crisis in Spain and to generate funds for the food ships that were being sent to relieve the suffering of the Spanish people. 


\section{Remaking of Picasso's Guernica as a Protest Banner (2012 - 2014)}

In 2012, Louise Purbrick, a colleague at the University of Brighton in the United Kingdom, issued a call to join in the remaking of Picasso's Guernica as a protest banner. Twelve artists and activists from Brighton responded to her invitation. ${ }^{4}$ At our meeting for the first time, one member of the collective, Peter Seddon, presented research he had conducted on the bombing of the Basque town of Gernika on April 26, 1937 and Picasso's artistic response to this attack. This prompted collective member, Maude Casey, to speak out about the number of drone attacks on civilians being carried out in the present day - at that meeting connections were also made between the rise in fascism in the 1930s and the growing presence of Islamophobia circulating in the $21^{\text {st }}$ century - and the links between fascism and militarism. Following several meetings, it was decided that the individual shapes that form the Guernica banner would be made by the collective and then sewn in place through a series of sewing events held in public spaces, with an open invitation for people to join in (Figure 2).

From the outset, it was intended that this remaking of Guernica would function as a protest banner. The banner was designed so that it would need to be carried by a group of people. It measures 1.45 meters high by 4.15 meters wide; to carry it, the design necessitates people to stand side by side, walking along together (Figure 3). In order to achieve an image on this scale, a reproduction of Picasso's Guernica was projected on a wall at the desired width of the banner. The main shapes forming Guernica were then traced on to paper so they could be worked on separately. Members of the collective each identified which motif they were most interested in working on, and the various components of the banner would thus be made by individuals, pairs or small groups.

I worked on the horse with Maude Casey and Lili Roseveare. What motivated this choice was the vivid expression of pain and suffering embodied in the horse, made explicit 
through the tension of its rigid tongue, gaping mouth and strained neck.

As Picasso was living in France in 1937, when he made Guernica, he depended largely on press reports to learn about what was occurring in his home country during the Spanish Civil War. News reports were also a vital source of insights to us between 2012 and 2013, when we were working on the banner. Maude Casey had been paying close attention to any attempts to record the numbers and identities of those killed in drone attacks, and I contributed a collection of newspaper articles from broadsheets, tabloids and local papers in the same period that reported on terrorism, drone attacks, fascist groups, militarism and border control. We thought of creating a collage of a selection of headlines and placing them on the horse (Figure 4). But when this work was shown to the collective, there was concern that the collage could result in the banner being misinterpreted as promoting rather than criticizing fascist ideals, and it was agreed that we should therefore abandon this approach. Ultimately, we decided to adhere closely to the shapes and forms of Picasso's motifs so that they could be clearly identified. But we did introduce some modifications. While the horse, which was drawn using fabric pen, follows the outline of Picasso's, the marks on its torso were turned into small human stick figures to symbolize the uncounted and unnamed people killed in recent drone attacks taking place in countries such as Afghanistan, Gaza, Iraq, Libya, Pakistan, Palestine, Syria, Somalia and Yemen (Figure 5). ${ }^{5}$ Lili Roseveare provided the braid used to create the tail of the horse. A suggestion was made that we incorporate some names of those killed in the tail, spelling first names through the placement of the braid. But, because we did not feel it right to select the names of some and neglect so many others, we decided ultimately to enable the tail to take on a more abstract form.

Pivotal to the development of the horse were conversations that occurred during its making - ones that focused on the appalling practices of using drones to kill civilians, the lack of accountability pertaining to those responsible for the order to attack and prejudices 
evident in the newspaper reporting. On consideration, it has become apparent that working collaboratively presented an important opportunity to present ideas to fellow collaborators in order to gain fresh perspectives on the realization of artistic ideas. This process of creative reflection clearly added exponentially to the realization of not only the horse but other motifs in the banner.

Helen Carnac, talking of a research interest in the role of communication in artistic practice she shares with Russell Martin and Paul Harper, observes: "Our common interest is in talk as an active component or process of creative practice" (Carnac 2013, 34). Carnac has observed the importance of tension in collaboration. Building on the work of Ann Galloway (2007), she asks:

What does this tension do, and how important is it? It seems it may be closely aligned to making and friction, tension that occurs when making work, yet is often occluded in the way that work goes out into the world. Often all we see is the finished artefact - none of the messiness or conversation from along the way (Carnac 2013, 34).

As a collective, we decided to show some of the "conversation from along the way" by providing evidence of a debate we had regarding the visual identity of the woman dragging herself along in the center-right of the Guernica banner. Carol Nicolou created the shape: she saw this figure as a freedom fighter and wanted to identify her as such through the use of badges representing a range of causes (Figure 6). Ultimately, however, we felt that the badges located the banner geographically and politically in a way that eroded its universality. 
The badges were consequently covered up with white fabric and the breasts of the figure embroidered mirroring the detail present on Picasso's Guernica (Figure 7).

The methods used to create the banner have qualities in common with those followed by first-wave feminists. Rozsika Parker $(2010,197)$ highlights the fact that Suffrage banners "daringly combined embroidery, paint, collage, and raised work". The banner is from this mixed-media tradition (Ashmore and Rajguru 2013). Needle and thread have been used to appliqué fabrics and embroider details but so too has glue been used to stick felt in place on the horse while fabric pen has been employed to draw in details on both the horse and the figure holding the lamp. Some fabric was stained to add texture and color, notably that used for the figure leaning out of the burning building, whilst these qualities were achieved in the motif of the mother holding her dead baby through the integration of fragments of recycled materials.

In the introduction to the book, Collaboration through Craft, the authors highlight the potential significance of materials individuals might use: "While theories that circulate around craft can sometimes seem to reduce materials to something inert, makers know that materials have their own lives, active qualities and movements" (Ravetz, Kettle and Felcey 2013). Aligned with this thinking, we consciously chose two fabrics with significant political meanings - Khadi and Kuffiyah - to incorporate into the banner, ones that enabled us to speak to the power of people uniting to change unsatisfactory systems of governance.

Collective member, Megha Rajguru, is from India she was able to source Khadi with the help of her sister located in the city of Pune. In a paper Rajguru and I co-authored on the banner (Ashmore and Rajguru 2013), we offered the following comments about the significance of this fabric and its use in the banner: 
Mahatma Gandhi introduced Khadi during the colonial struggles in India to boycott imported textiles and ultimately promote Swadeshi or home rule. Khadi was homespun and handwoven to make fabric for clothing, which became an important collective act of protest. We have used Khadi in the making of the homes and buildings depicted in Guernica [see Figure 8]: a poetic link with Gandhi's campaign for home rule.

The banner travelled to Ahmedabad in Gujarat for the 2013 Design History Society conference. Ahmedabad is home of Gandhi's non-violent movement, and the fabric Khadi. These facts propelled us to take the banner to the city and conduct a sewing in the grounds of the National Institute of Design, where students still weave Khadi fabric.

Part of the bull's body is also made in Khadi. The bull is sometimes interpreted as signifying fascism and at other times is thought to represent activism. Interestingly in contemporary India, Khadi is an icon of Indian nationalism, and yet it also fluctuates between an association with Swadeshi (home rule) that Gandhi fought for, and post-independence political corruption. Dipesh Chakrabarty writing in 2001 in the journal of Postcolonial Studies highlights this paradox when discussing Khadi's presence in public life in India as: "a semiotic of 'corruption' $[\ldots]$ that $[\ldots]$ once read 'purity' and 'renunciation' and now [reads] as corruption and thievery" (Chakrabarty 2001).

Another shape on the banner that incorporates a textile with political significance is the dying soldier. Trinidad Catalan collective banner-maker and member of the Palestine Solidarity Campaign proposed the use of Kefiyyeh to make a link to the Palestinian cause promoting peace and justice for the Palestinians. After some discussion about the dying 
soldier with his broken sword, the decision was made to identify him as Palestinian, using a Kefiyyeh, a widely-recognized fabric employed as a form of protest by Palestinians since the 1960s (Figure 9). In our banner the soldier holds an olive branch, which symbolizes peace but also evokes memories of the ancient olive trees bulldozed from Palestinian farmers' lands in order to build Israeli settlements (Ashmore and Rajguru 2013).

In the connection it makes between historic and current government-led attacks on civilian populations, the banner has functioned as an effective tool for incorporation in protest actions. The banner's website ("Home" 2015) describes this protest activity thus far:

Its first walk of protest was against the EDL [English Defense League - far right group] marching in Brighton in April 2014. Since then, it has walked in protest at the EDO MBM Ltd weapons component factory in Moulsecoomb Brighton [which supplies the Israeli army], and at four protests against the aerial bombardment of the civilian population of Gaza [in the Summer of 2014].

Indeed, by appearing in a range of different settings - from galleries, ${ }^{6}$ to public protests ${ }^{7}$ and at political events aligned with the collective makers' interests ${ }^{8}$ - the banner has accumulated its own historical significance.

Particularly important also have been public sewing events. While the deadlines set for these ensured we had all progressed to the point where the main shapes could be put in place to form the banner, and had the practical benefit of keeping us focused on the task at hand, they also provided opportunities of showing the work to the public. The first two public sewing events occurred in the center of Brighton at the Jubilee Library on June 16 and 23, 
2013, and various others followed. ${ }^{9}$ By being prominently situated near the entrance to the main room, everyone who came into the library was aware of the sewing. The banner was laid flat across several tables. In preparation for these, we had created, placed and tacked the main shapes on to the black background, and some of the makers sat around the table, stitching the shapes on to the background whilst others were talking with interested members of the public and instructing those with no experience how to sew blanket stitch - the stitch we used to hold the shapes in place and which anchored the material securely. The color of the thread used varied from section to section. Consequently, we found it necessary to create a diagram of the banner which we took to each public sewing that detailed what color thread to use where.

As noted, conversation and reflection between makers played an important part in the creation of the banner. Relatedly, we found that choosing to sew in public places, particularly those with good footfall, created a steady stream of engagement. Some people recognized the use of Guernica, while others were curious about what we were doing and why. The sewing events firmly placed Picasso, the Guernica, militarism, civilian casualties, fascism and sewing as topics up for discussion. In line with the ideas of David Gauntlett (2011), we experienced that the act of sewing together formed a valuable material connection recorded in the banner that was visible to all participants, makers and audience members. Participation, we observed, could happen on a number of levels. For some, sewing and listening to the conversations round the table was enough, whereas for others there was an outpouring of feelings and stories relating to the conflicts the banner references. Some came to sew a number of times, at different venues, seeming to enjoy feeling part of a political art project. The banner makers also noticed an interesting silent dialogue that seems to happen between the sewer, the stitch and the cloth, through which a temporary placement of fabric becomes permanent, and individuals' actions contribute to a collective statement against aerial attacks 
on civilian populations.

The Nature of the Beast (2009-2010)

Since 1985, the copy of the Guernica in the Rockerfeller collection had been installed in the Security Council corridor of the United Nations headquarters in New York where announcements to the press are made (Figure 10). In the exhibition by London-based Polish artist Goshka Macuga titled The Nature of the Beast, a direct link was created to the moment Colin Powell made his weapons of mass destruction speech in that space, signaling the invasion of Iraq in 2003. The Tapestry had been covered up in advance of this speech with blue drapery - a decision that was explained by a diplomat interviewed in The Washington Times (3 Feb. 2003) as follows:

It would not be an appropriate background if the ambassador of the United States at the UN John Negroponte, or Colin Powell, talk about war surrounded with women, children and animals shouting with horror and showing the suffering of the bombings (Pisik 2013).

In The Nature of the Beast, the Tapestry - which had been borrowed - is set against a blue curtain reminiscent of that in the Security Council corridor of the United Nations headquarters (Figure 11). The blue cloth in this context thus becomes a material associated with a distinct political moment. ${ }^{10}$

In a small area of the exhibition, projections of films from Afghanistan and Iraq were shown throughout the day, and these were updated once a month for the duration of the 
exhibition. Some made by amateurs and others by professionals, this filmic presence enabled an important documentary element of the Iraq and Afghanistan conflicts to be included in the exhibition.

The gallery space also incorporated a circular meeting table, one designed to evoke the assembly room in the UN Security Council. Within each section of the table archival material was included. Some was from the Whitechapel Archive on the exhibition of Pablo Picasso's Guernica at the Gallery in 1939 (when, as mentioned, boots were collected), a time when anti-fascist activities were being organized in the East End of London, whilst other material was more contemporary and focused on Iraq.

As with the banner, the exhibition created a platform for socio-political engagement. In parallel to the public events involving the sewing of motifs on to the banner, the Nature of the Beast created a place for public meetings. Groups and individuals could book the gallery space for free to hold their meetings on two conditions: the gallery had to remain open to the public to observe the meetings, and the meetings had to be documented and these records donated to the Whitechapel Gallery Archive. This idea of adding to the Archive was thought of by Nayia Yiakoumaki who was writing a PhD dissertation titled "Curate the Archive, or Archive the Curator."11. Serving as the site for both the display of this historical material and or meetings, the table connected politics and conflicts of the past with those of the present.

Many of the groups meeting at the exhibition were local. Pointing to a strong presence of collective action in the area, these encompassed groups from Universities and Colleges, local and national arts and cultural bodies, charities and activist groups. For example, a meeting was held on April 23, 2009 that involved people from the G20 Meltdown, an anticapitalist protest that is held on 1 April (Goshka Macuga The Nature of the Beast 2009, 42). The exhibition also served as the forum for a meeting on July 12, 2009, of the Survivors Fund, "a London based international organization representing and supporting survivors of 
the Rwandan genocide" (Goshka Macuga The Nature of the Beast 2009, 48), who met to mark the $15^{\text {th }}$ Anniversary of that genocide, sharing testimonies of survivors. Sally O'Reilly, writing in the exhibition catalogue, reflected: "It is a sign of the times, perhaps, that when the public feel at a remove from operations of power at national and international levels, they group and regroup at the level of the local" (Goshka Macuga The Nature of the Beast 2009, $38)$.

If The Nature of the Beast and the banner both served to harness activist activity, they also have in common a use of fabric associatively. As indicated, the banner's incorporation of Picasso's formal language via Khadi and Kefiyyeh serves to suggest commonalities between the politics of different geographies, the setting of the Rockefeller tapestry against a blue curtain - chosen to match the United Nations blue - alludes to the cover up in New York of the terrible impact of the second invasion of Iraq on civilian populations.

\section{The Keiskamma Guernica (2010)}

The Keiskamma Guernica, completed in 2010 (Figure 12) and first exhibited at the National Arts Festival held annually in Grahamstown, is a work with the same dimensions as Picasso's original. Made by the Keiskamma Art Project, a collective from the villages of Hamburg and Bodiam in the Eastern Cape of South Africa with a primarily female membership and that was initiated by medical doctor and artist, Carol Hofmeyr, in 2000, it tells the story of the impact of HIV/IDS on the people living in the Peddie region and it emphasizes the real human cost of this health crisis.

Paralleling Picasso's use of his own Guernica to combat fascism, the makers of The Keiskamma Guernica have articulated resistance to their own government's sacrifice of the wellbeing of some of its poorest citizens through an inadequate response to the health care 
needs of this population. This translation of Picasso's Guernica shifts the focus from fascism to the HIV/AIDS crisis in South Africa by adapting Picasso's visual forms in such a way as to invoke reference to impact of the disease as well as to local textiles and cultural and religious practices amongst the amaXhosa (see Schmahmann 2015; 2016). The motifs and symbols used communicate a complex range of emotions surrounding the witnessing and experiencing of pain and suffering as a consequence of the AIDS epidemic. The female on the left of the Keiskamma Guernica holds her lifeless adult child, the women on the bottom right are gathered together grieving at a funeral for the loss of a son, and running the length of the bottom edge of the textile are the initials of those who died at the hospice. Thus, in a way more explicit than the banner, the Keiskamma Guernica is an example of how one representation of an historical moment and culturally specific situation may be translated into another totally different one.

The powerful history of the fabrics used to create The Keiskamma Guernica is significant. The work includes some recycled fabric from skirts that local women had dyed with natural clay as well as beadwork AIDS ribbons that had been made by project members a year or two earlier. ${ }^{12}$ More significantly, the grey background is formed from the actual blankets used by sufferers of AIDS at the hospice established by Carol Hofmeyr in Hamburg $^{13}$ (Figure 13) - a facility that, through lack of funding as well as government policy, had been obliged to cease offering hospitalization to the very ill in 2009 , shortly before work on The Keiskamma Guernica commenced (Schmahmann 2015, 9). Other remakings of Guernica I have discussed certainly used materials with political meanings but they did not have the specific provenance of the blankets. In The Keiskamma Guernica the blankets used as a background also made it possible for blanket-sized sections to be worked on by smaller groups of embroiderers. 


\section{Conclusion}

Picasso's Guernica, I have suggested, has offered important opportunities for linking art and activism. Focusing on a banner in which I was involved while also drawing reference to Goshka Macuga's exhibition including the reworking of the Guernica in the Rockefeller collection as well as The Keiskamma Guernica from South Africa. I have suggested how all three have created messages both through their reiteration or adaptation of motifs in the original and via fabrics from which they are made (or, in the case of the Macuga intervention, cloth with which it was juxtaposed). All three, I have also suggested, have substituted the lone maker (in Picasso's case) with collective production, taking advantage of the opportunities that such as approach involves for testing and sharing ideas. The banner and Macuga exhibition involved public participation also, thus in a sense providing a contemporary parallel to the rallying of political support Picasso hoped his Guernica would enable.

Picasso's painting has indeed proved a powerful prompt for artists, curators, activists and concerned citizens to view art as a means of decisively opposing governments responsible for the suffering of civilian populations.

\section{Bibliography}

Ashmore, Nicola. 2016a. "Remaking Picasso’s Guernica a banner.” Accessed April 1. http://guernicaremakings.com/about/remaking-picassos-guernica-a-banner/

Ashmore, Nicola. 2016b. "The Nature of the Beast." Accessed April 1. http://guernicaremakings.com/about/the-nature-of-the-beast/ 
Ashmore, Nicola. 2016 c. "The Keiskamma Guernica.” Accessed April 1.

http://guernicaremakings.com/about/keiskamma-guernica-2/

Ashmore, Nicola and Megha Rajguru. 2013. "Remaking Picasso's Guernica as a banner." Paper presented at the Subversive Stitch Revisited: The Politics of Cloth, V\&A Museum, London, November 29-30.

Ashmore, Nicola and Megha Rajguru. 2014. “Remaking Picasso's Guernica as a banner, a work of art; an act of protest." Paper presented at the Annual Design History Conference, Design for War and Peace, Oxford, 4-6 September.

Arnheim, Rudolf. 1964. Picasso's Guernica: the genesis of a painting. London: Faber..

BBC News. 2003. “"Million' march against Iraq war”. February 16. Accessed July 12013. http://news.bbc.co.uk/1/hi/uk/2765041.stm

Bowcott, Owen. 2014. "Drone strikes by US may violate international law, says UN." Guardian, 18 Oct. 2013. Web. May 17.

Carnac, Helen . 2013. "Moving Things around...Collaboration and Dynamic Change" in Collaboration Through Craft. London: Bloomsbury,. 31 - 44.

Casey, Maude. 2013. " $21^{\text {st }}$ Century Aerial Bombardment” in Remaking Picasso's Guernica as a Protest Banner. Brighton. Leaflet. 2013. 
Chakrabarty, Dipesh. "Clothing the Political Man: A Reading of the Use of Khadi/White in Indian Public Life.” Postcolonial Studies, Vol. 4, No. 1, (2001): 27-38.

Galloway, Ann. 2007. "Seams and Scars, or How to Locate Accountability in Collaborative Work." In (Un)Common Ground Creative Encounters across Sectors and Disciplines, edited by C. Brickwood, B. Ferran, D. Garcia and T.Putnam, Amsterdam: BIS Publishers,.

Gaunlett, David. 2011. Making is Connecting. Cambridge: Polity.

Goshka Macuga The Nature of the Beast. 2009. London: Whitechapel Gallery.

“Home.” 2015. Remaking Picasso’s Guernica. Accessed July 10.

https://remakingpicassosguernica.wordpress.com

Parker, Rozsika. 2010. The Subversive Stitch: embroidery and the making of the feminine.

London: IB Taurus,.

Pisik, Betsy. 2003. "UN Report: The Picasso Cover-up.” The Washington Times, February 3.

Ravetz, Amanda, Alice Kettle and Helen Felcey. 2013. Collaboration through Craft. London: Bloomsbury.

Russell, Frank. 1979. Picasso's Guernica: The Labyrinth of Narrative and Vision. New York: Abner Schram.. 
Salanova, Concha Calvo. 2017. 'Reportage sur l'evolution de 'Guernica' (Photo Report of the Evolution of 'Guernica').” Museo Nacional Centro De Arte Reina Sophia. Accessed: 19 February. http://www.museoreinasofia.es/en/collection/artwork/reportage-sur-levolutionguernica-photo-report-evolution-guernica-1

Schmahmann, Brenda. 2015. "Patching up a Community in Distress: HIV/AIDS and the Keiskamma Guenrica". African Arts 48 (4)): 6-21.

Schmahmann, Brenda. The Keiskamma Art Project: Restoring hope and Livelihoods. Cape Town: Print Matters Heritage, 2016.

Schama, Simon. 2006. Power of Art. Picasso. BBC. DVD.

Van Hensbergen, Gijs. 2004. Guernica: the Biography of a Twentieth Century Icon. London: Bloomsbury.

Wells, K.L.H. 2015. “Rockefeller's Guernica and the collection of modern copies”. Journal of the History of Collections 27 (2): 257-277.

\section{Notes}

\footnotetext{
${ }^{1}$ Altman, Cynthia. Interview with the author, September 2, 2015.

${ }^{2}$ Altman, Cynthia. Interview with the author, September 2, 2015.

${ }^{3}$ Interestingly a postcard of Guernica has entered into Picasso legend. During World War
} 
Two when the Germans occupied Paris (1940-44), Nazi officers would regularly visit Picasso in his studio. The story goes that a Gestapo officer picked up a postcard of Guernica and asked Picasso: "Did you do this?" Picasso responded: "No, you did!" This story demonstrates the power of Guernica in its reproduced form (Schama 2006).

${ }^{4}$ The collective members are involved with the following: Amnesty International Brighton and Hove; Brighton Anti-Fascists; Brighton Voices in Exile; Gatwick Detainee Visitors Group; Migrant English Project; Palestine Solidarity; Campaign Brighton and Hove; University of Brighton: artists/activists; Women's International League for Peace and Freedom.

${ }^{5}$ In her writing on drone attacks Maude Casey states: "No one knows how many people have been killed by them and no one knows the names of all the people killed" (Casey 2013). This is significant and, as Ben Emmerson, UN Special Reporter on Counter Terrorism, has observed, this current state reflects a "hurdle to transparency," (Bowcott 2013) which has created an accountability vacuum.

${ }^{6}$ Galleries the banner has been exhibited in: Art, Refuge and Resistance, Grand Parade Café Gallery, Brighton, UK, 23 October - 14 November 2015; Exhibited to coincide with the major exhibition Conscience and Conflict: British Artists and the Spanish Civil War, Pallant House Gallery, Chichester, UK, 8 November 2014 - 15 February 2015; Yoko Ono’s Meltdown Festival online, on the Guardian Witness site, June 2013.

${ }^{7}$ Protests the banner has been present at: Protest against Trump's Inauguration, London, UK, 21 January 2017; White Poppy Wreath Laying, Brighton, UK, 13 November 2016; Cable Street $80^{\text {th }}$ Anniversary, London, UK, 9 October 2016; Open Europe, Open the Borders, Dover, UK, 2 April 2016; CND demonstration and European March for the Refugees Rights, London, UK, 27 February 2016; Walked in protest at the EDO MBM Ltd weapons 
component factory in Moulscoomb Brighton, UK, and at four protests against the aerial bombardment of the civilian population of Gaza, summer 2014; Stop MFE, 27 April 2014.

${ }^{8}$ Political events the banner has been present at: Brighton \& Palestinian Artists together: Brighton to Palestine with Love, St Michael's Church, Brighton, UK, 4 June 2016; Refugee Tales at the Hawth Theatre Crawley, UK, 21 June 2015; Brighton \& Palestinian Artists together: Brighton to Palestine with Love, The Brighthelm Church and Community Centre, Brighton, UK, 21 May 2015; Levelling out Racism: Stop MfE's international picnic, The Level, Brighton, 26 April 2015; Guernica, International Brigade Memorial Trust conference, The Manchester Conference Centre, Manchester, UK, 7 March 2015; Pensioners Association Meeting, Patcham Lodge, Brighton, 13 January 2015; Cuban Solidarity Campaign, Brighthelm Centre, Brighton, UK, 3 November 2014; Brighton Secular Humanists, The Sussex, Hove, 3 September 2014; Women's International League for Peace and Freedom AGM, The Friends Meeting House, Brighton, 12 April 2014.

${ }^{9}$ The following is a list of all the public sewing events held:

August 16, 2014, To Gypsyland, 198 Gallery, Brixton, London June 7, 2014, Local Name: Unknown .... Gypsies?, Phoenix Gallery, Brighton April 19, 2014, Art vs Fascism, Cowley Club, Brighton March 8, 2014, Working with Monica Ross, University of Brighton, Brighton November 29, 2013, The Subversive Stitch Revisited, V\&A, London October 12, 2013, Darn that Picasso: conversations and craftivism, Working Class Movement Library, Manchester

October 5, 2013, Resisting the New Racism, Brighthelm Centre, Brighton September 5, 2013, National Institute of Design, Ahmedabad, India August 10, 2013, Phoenix Art Brighton 
July 21, 2013, Friends Meeting House, Brighton

June 23, 2013, Jubilee Library, Brighton

16 June 2013, Jubilee Library, Brighton

${ }^{10}$ There is another significant reference to Iraq in the exhibition in the form of a bronze statue of Powell giving his infamous speech. The pose is synonymous with the moment Powell held up a vial whilst talking about the threat a chemical attack poses which formed the basis of his argument to invade Iraq.

${ }^{11}$ Nayia Yiakoumaki, Interview with the author, 18 June 2015

${ }^{12}$ Carol Hofmeyr, Interview with the author, July 29, 2015.

${ }^{13}$ Carol Hofmeyr, Interview with the author, July 29, 2015. 